\title{
The Impact of Environmentally Friendly Innovations on Value Added
}

\author{
Christian Soltmann - Tobias Stucki · Martin Woerter
}

Accepted: 21 August 2014 / Published online: 9 October 2014

C Springer Science+Business Media Dordrecht 2014

\begin{abstract}
While recent literature has focused on explaining the determinants of green innovations, it is not well understood how such innovations affect performance. To analyse the relationship between green innovation and performance, new industry-level panel data were exploited: these include 12 OECD countries, the whole manufacturing sector and a period of 30 years. The results show that green inventions are U-shape related to performance. However, the turning point is quite high and hence only relevant for a few industries. This indicates that-given the current level of green promotion-market incentives alone are not sufficient to allow the green invention activities of industries to rise considerably. To verify these results and to get a better understanding of the mechanisms in the green market, we finally made several interviews with multinational firms that have a good understanding of what happens on the global market of green innovation.
\end{abstract}

Keywords Innovation $\cdot R \& D \cdot$ Patents $\cdot$ Environment $\cdot$ Technological change $\cdot$ Performance JEL Classification $\mathrm{O} 30 \cdot \mathrm{O} 34 \cdot \mathrm{Q} 55$

\section{Introduction}

Empirical research on environmental innovations provides us with a good understanding of what leads to innovation in environmental technologies. In particular, the linkage between

\footnotetext{
C. Soltmann

European Patent Office, 1030 Vienna, Austria

e-mail: csoltmann@epo.org
}

T. Stucki $(\bowtie) \cdot$ M. Woerter

KOF Swiss Economic Institute, ETH Zurich, 8092 Zurich, Switzerland

e-mail: stucki@kof.ethz.ch

M. Woerter

e-mail: woerter@kof.ethz.ch 


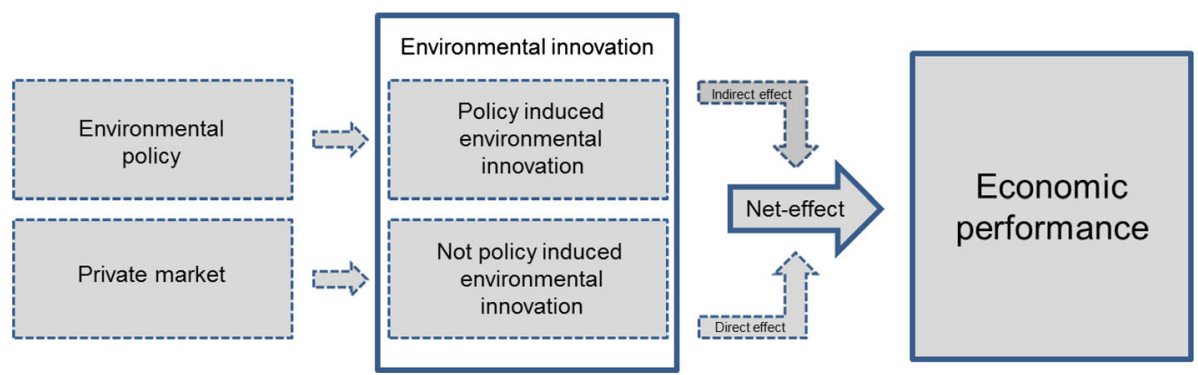

Fig. 1 Causality chain of the innovation effect. Notes Only the parts of the causality chain with a solid outline are directly observed in our data

green innovation and policy has been a major area of research in environmental economics. For a comprehensive overview of the literature see Popp et al. (2010).

Most investigations stop at the innovation level and do not examine whether environmental innovations are profitable or when they are profitable. There are only a few recent exceptions. Based on firm-level survey data for seven OECD countries collected in 2003, Lanoie et al. (2011) identify a positive effect of environmental R\&D on business performance. Rexhäuser and Rammer (2014) use a German firm-level survey conducted in 2009 and find that environmental process innovation that increases efficiency has a positive effect on firm profitability, while the effect of externality reducing process innovation is negative. The main focus of both studies, however, is on identifying the net-effect of environmental policy on economic performance. Probably most related to our study is the paper by Marin (2014). Based on Italian firm-level balance sheet data for the period 2000-2007, he finds that environmental patents mostly do not have a significant effect on firm productivity, while the effect of non-environmental patents is statistically significant positive. In the study at hand we try to broaden the evidence by analysing the link between environmental innovation and performance (measured as value added) based on an industry level data set that includes 12 OECD countries, the whole manufacturing sector and a period of 30 years.

Since environmental innovations are suffering from a "double externality" problem, policy measures are often used to stimulate environmental innovation. As stated in Porter and van der Linde (1995), economic performance can thus not only be directly affected by environmental innovation, but also indirectly by policy-induced innovation (see Fig. 1). To be able to identify the direct effect of environmental innovation on performance, a control for the indirect effects of environmental policy would be required. However, such a measure is hardly possible to find on a disaggregated level. ${ }^{1}$ Accordingly, we cannot disentangle the two effects and thus measure a net-effect of environmental innovation. Nevertheless, the analysis at hand is of high political relevance, as it indicates whether the current political environment is already sufficient to render environmental innovations profitable (positive net-effect) or if it has to be further adjusted.

Our research is based on a broad empirical basis. We use patent data to identify green and non-green inventions. Patent documents considered as covering green inventions are identified according to the OECD Indicator of Environmental Technologies (see OECD 2012) that distinguishes seven environmental areas, i.e. (a) general environmental management, (b)

\footnotetext{
1 In our case such a policy measure should be available on the industry level, a period of 30 years, 12 OECD countries and, as the effects may differ by type of policy, it should represent the whole policy environment (e.g. push and pull policies). As we do not have such a measure, we control only for country specific policy shocks by including country-time fixed effects (see Sect. 4).
} 
energy generation from renewable and non-fossil sources, (c) combustion technologies with mitigation potential, (d) technologies specific to climate change mitigation, (e) technologies with potential or indirect contribution to emission mitigation, (f) emission abatement and fuel efficiency in transportation, and ( $\mathrm{g}$ ) energy efficiency in buildings and lighting. If an invention can be assigned to one of these sub-groups (a to g), it is counted as a green invention; otherwise it is counted as a non-green invention. Based on these counts and using the perpetual inventory method, we can define a quantitative measure to analyse non-linear effects of green inventions on performance.

The data used for our analysis is aggregated on an industry level. The use of aggregated data has several advantages. Firstly, it allows us to use the OECD STAN database to estimate a standard Cobb-Douglas production function. Secondly, it allows us to generate a data set that cover the whole manufacturing sector (22 industries), the most important countries for green invention (12 OECD countries that are responsible for $95 \%$ of all green patents and total patents worldwide) and this over a period of 30 years. Furthermore, the balanced data set allows us to control for correlated unobserved heterogeneity between the industries of the different countries.

The results show that green inventions are U-shape related to performance on an industry level. The turning point is, however, quite high and thus only relevant for a few industries. Accordingly, green innovation has not been profitable for most of the industries so far. Hence, it is unlikely that green innovation will proceed without policy interventions to a level where environmentally unfriendly technologies would be replaced by green technologies in due time. For this reason, we think that the current answer to Popp's (Popp 2005, p. 224) question as to whether environmental innovation will proceed without policy adjustments is probably no.

The paper is organised as follows: Sect. 2 two provides the conceptual background and the research questions. Section 3 describes the data. In Sect. 4 we show how we tested the hypotheses empirically. Section 5 presents the results, and in Sect. 6 we present our conclusions.

\section{Conceptual Background and Research Questions}

As we cannot control for the political environment on the industry level, we cannot properly disentangle the direct innovation effect and the indirect, policy induced effect. Accordingly, our innovation variable measures a net-effect of both. To get an idea about the direction of this net-effect, we first have to understand the two underlying effects. In doing so, we start with the direct innovation effect.

There are a number of empirical investigations (e.g., Crepon et al. 1998) that reveal a positive relationship between inventive output (measured through innovative sales or patent applications) and the performance of a firm. ${ }^{2}$ This standard result in innovation economics cannot be taken for granted if we look at green inventions. The "green" aspect of inventions is a relatively recent phenomenon that slowly started in the $80 \mathrm{~s}^{3}$ and increasingly pushes firms to discover new technological paths and to invest in new technologies.

\footnotetext{
2 Please notice that our conceptual framework refers to the firm level and our empirical investigation is based on more aggregated industry data (see, e.g., Aghion et al. (2005) for a similar practice).

3 Only very few green inventions were patented before 1980 (see Fig. 2). The invention activities increased in the 90 s and only in the last decade we see a considerable rise in green invention activities relative to other inventions.
} 

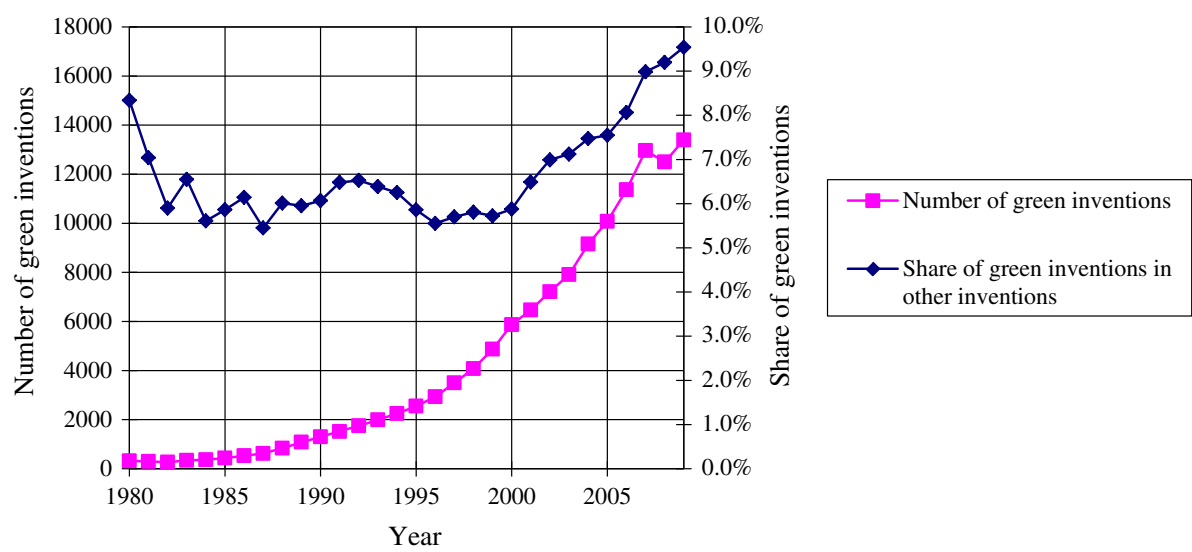

Fig. 2 Development of green inventions worldwide, 1980-2009. Notes To reduce the problem of double counts of inventions, this information is based on world-aggregated data and is not restricted to countries and industries that are in our estimation sample

Especially in an initial technological phase, there are several reasons why firms are unable to develop green technologies in a profitable way. The development of green products and processes usually implies investing in technologies that lie beyond the firm's traditional technological scope (see Noci and Verganti 1999) and thus challenges a firm's capability profile in terms of knowledge creation and technology development. To meet these challenges, at least a modification, if not a change, of the firm's resource base is required. This could be a costly task because firms may not have the capacity to alter the technological basis. If they identify useful external knowledge, this knowledge may be non-tradable due to its 'tacit' character, or it is only available at a very high price (Teece et al. 1997). Costs could also result from the coordination of technological activities within firms or between firms or institutions if green technologies are investigated or acquired through research cooperation.

It is not a change in technology alone that increases costs in the initial phase. In addition to technology, business processes and working routines also have to be adapted or even newly developed (Danneels 2002). Moreover, it may be necessary to hire new employees, constitute new departments or acquire specialised firms, as we observed in other sectors that underwent considerable technological changes (e.g., the increase of biotechnology in the pharmaceutical industry).

Furthermore, financial market imperfections that are normally associated with innovation activities (see Arrow 1962, p. 172) are even more pronounced for green innovation. As argued above green innovations carry a high technical risk as they often imply investing in technologies that lie beyond the firm's traditional technological scope. Additionally, commercial uncertainty arises from unclear market developments (Aghion et al. 2009). Hence, potential external investors are hardly willing to invest in such projects and financial markets are not efficient as far as technological investments are concerned. As a consequence, access to external capital to finance green innovation is likely to be constrained.

While the discussion above has shown that costs for green innovation can be substantially larger than for traditional innovation activities, there are also demand-side factors that reduce a firm's returns to green innovation compared with traditional innovation activities. The demand for a product shapes the incentives to innovate (Dasgupta and Stiglitz 1980). Demand is expressed by the willingness to pay for newer products. As the greatest benefits 
from green innovation compared with traditional innovation are likely to be public rather than private ones, the exclusivity of green product benefits is not given (e.g., the benefits of emission reduction in the case of electro cars). Accordingly, the willingness to pay for green products will be low (see, e.g., Beise and Rennings 2005; Faber and Frenken 2009; Hall and Helmers 2011). Consequently, the demand for green innovation is strongly related to political efforts to internalize negative external effects from environmentally unfriendly products and create markets for green innovations. There are at least two options, either there are policy measures that increase the demand for green innovation (e.g., mandatory standards for the use of chemicals in products or to rise energy prices that increase incentives for energy reduction), or governments themselves increase their demand for green innovation (e.g., energy generation from renewable sources). However, such policy-induced markets are hardly to predict for a longer period of time. Economic downturns can change the political agenda and limit public means to invest in energy generation from renewable sources, unforeseen political events (e.g. international conflicts) or technological shocks (e.g. shale gas) can change environmental policies as well and as a consequence expected markets will not evolve. Hence, green technology investments are very risky, especially for smaller firms, since considerable upfront investments are necessary and small firms are usually not in a position to diversify their technological activities sufficiently in order to be not hit considerably by unexpected policy (market) developments. This makes it obvious that for the time being green technology investments primarily increase the costs with uncertain returns in the future.

To sum up, the discussion above has shown that while the costs of technological diversification in green technology fields can be considerable, the commercialisation of these new technologies is difficult. Prices of green products are unlikely to be competitive, at least in the initial phase when production costs are relatively high. Accordingly, we expect that an increase of the green knowledge stock does significantly decrease the performance of a firm or an industry.

Whether the expected negative direct innovation effect can be compensated by policyinduced innovation activities is unclear. The effect of induced innovation activities represents the indirect environmental policy effect on economic performance. Size and direction of these policy effects strongly depend on the chosen mix of policies. While supply-side subsidies should indirectly stimulate economic performance as firms/industries receive public money for their innovation activities, norms/standards may have a negative effect as the costs for the enforced innovation outweigh potential efficiency gains. ${ }^{4}$ In the end it thus seems to be an empirical questions whether the net-effect of environmentally friendly innovation activities are positively related to performance or not. Accordingly, we formulate the following research question:

R1: Are green innovation activities (independent whether they are policy induced or not) positively linked to performance?

As argued above, research into new knowledge is expensive. Accordingly, one cannot expect positive marginal returns from such innovation activities right from the beginning. However, increasing returns to scale are expected in research (see Henderson and Cockburn 1996, or Figueiredo 2002, for the steel industry), whereupon the impact of green inventions on performance should increase as the quantity of knowledge increases.

Building up a stock of knowledge involves substantial fixed costs. It takes considerable investment, not only in new technological knowledge, but also in additional training of employees, new equipment, or learning-by-searching (see Malerba 1992). Accordingly,

4 For an overview of the effectiveness of policies see Popp et al. (2010). 
increasing returns to scale are expected. The fixed costs only pay off if green innovation activities exceed a certain limit. If there are increasing returns to scale in green research, a firm moves from expensive 'exploration' of new knowledge to the less expensive 'exploitation' of existing knowledge (see March 1991; Quintana-García and Benavides-Velasco 2008), once it decides to further increase its knowledge stock. Our second research question reads as follows:

R2: Do we observe increasing returns to scale from green innovation activities?

\section{Description of the Data}

We use inventions in order to measure the green invention activities of an industry. Although patent statistics have many disadvantages in measuring invention output (see Aghion et al. 2012), they are a rather good proxy for input because there is a strong relationship between the number of patents and R\&D expenditure (see Grilliches 1990). Despite the fact that not all inventions are patentable and smaller firms are more reluctant to patent than larger firms, patent counts are still the best available source of data on innovation activities as it is readily available and comparable across countries (see Johnstone et al. 2010). This is especially true for green technological activities, since the OECD (2012) provides a definition of green technologies based on the patent classification.

For the paper at hand, patent information is gathered in cooperation with the Swiss Federal Institute of Intellectual Property (IPI), based on a three-step procedure.

In a first step we identified all the inventions from the 12 countries Austria, Denmark, Finland, France, Germany, Italy, Japan, the Netherlands, Sweden, Switzerland, the United Kingdom and the United States which in sum account for about $95 \%$ of all inventions worldwide. In doing so the following specifications and clarifications have to be made:

a) In order to assign patents to countries, the applicant's country of residence or the inventor's country of residence may be chosen. We assigned patents according to the applicant's address. Since only those inventions were selected for which at least one PCT (Patent Cooperation Treaty) application was filed, the applicant's address was generally available. ${ }^{5}$ Patent applications are usually costly. Moreover, the fees for an international patent application under the PCT are generally higher than those for a national or regional patent application. It seems likely that companies only use the PCT application route if they expect the inventions in question to have a significant commercial potential on the international level.

b) We used patent data provided by the European Patent Office (EPO) and by Thomson Reuters in order to identify relevant inventions. We did not look at single patents. Patents were grouped into patent families (inventions) instead according to the Derwent World Patents Index patent family definition of Thomson Reuters (peer-review procedure). This approach has the advantage that distortions caused by different national granting procedures and different application attitudes are mitigated (e.g., in the United States a higher number of single applications than in Europe tends to be filed for one invention).

5 We may also have used the inventor's address instead. However, there may be a risk of distorting the analysis, especially for smaller countries, because the inventor may not live in the country where the invention occurs. Conversely, by using the applicant's address the analysis may be biased by patent applications from multinationals for which the country of residence of the applicant possibly differs from the country where the invention occurred. In order to investigate if there are considerable differences, we took both the inventor's information and the applicant's information for Germany. In fact, we did not see any significant differences between the analysis based on the inventor's and applicant's address for that country. 
In a second step the inventions identified in the first step then were grouped into green and non-green patents. Green patents are a sub-group of patents that are selected according to the OECD Indicator of Environmental Technologies (see OECD 2012). Based on the International Patent Classification (at times complemented with ECLA codes ${ }^{6}$ ), the OECD definition distinguishes seven environmental areas, i.e. (a) general environmental management, (b) energy generation from renewable and non-fossil sources, (c) combustion technologies with mitigation potential, (d) technologies specific to climate change mitigation, (e) technologies with potential or indirect contribution to emission mitigation, (f) emission abatement and fuel efficiency in transportation, and ( $\mathrm{g}$ ) energy efficiency in buildings and lighting. All inventions that could not be aligned to one of these groups were defined as non-green.

Finally, in a third step we align the inventions identified in the first step with industry classes, as the dependent variable and some control variables are classified by industrial sectors and not according to the IPC technology classes. Schmoch et al. (2003) developed a concordance scheme that links technology fields of the patent statistics to industry classes. ${ }^{7}$ On the basis of this concordance scheme we could thus assign all the green inventions - that were previously identified based on the OECD classification - and the non-green inventions to 22 manufacturing industry classes either at the NACE two- or three-digit level. ${ }^{8}$ In comparison with invention data at the firm level, aggregating inventions on an industry level should reduce potential problems with invention waves within a firm.

Finally, we thus have measures for the total number of green and non-green inventions from 12 countries (Austria, Denmark, Finland, France, Germany, Italy, Japan, the Netherlands, Sweden, Switzerland, the United Kingdom and the United States), 22 industries (either NACE two or three-digit level of the whole manufacturing sector except 'printing and publishing' and 'recycling') and a period of 30 years (1980-2009). This yields a data set of 7,920 observations. Because of missing values for some model variables, the number of observations that could be used for econometric estimations is significantly lower.

Figure 2 shows the aggregated development of green inventions over time. In 1980, the beginning of our sample, only a few green inventions were registered. The number of green inventions remained very low during the following 5 years. Between 1985 and 1995, the number slightly increased. The increase was, however, not disproportionally high compared with other inventions. A sharp increase in the number of green inventions can be observed since 1995. In 2009, 13,397 green inventions were protected worldwide. While the share of green inventions was mostly stable in the initial stage, green inventions have increased disproportionally since 2000. In 2009, nearly $9 \%$ of all inventions were classified as green.

Detailed descriptive statistics for our disaggregated invention data is presented in Table 1. Most green inventions are found in the industries 'machinery' (24\%), 'chemicals (excluding pharmaceuticals)' (18\%), 'motor vehicles' (12\%) and 'electrical machinery and apparatus' (11\%). The two industries 'motor vehicles' and 'electrical machinery and apparatus' are at the same time the most green-intensive industries.

\footnotetext{
6 The European classification system (ECLA) is an extension of the IPC with about twice as many classification codes.

7 Lybbert and Zolas (2012), suggest new methods for constructing concordances. In comparing different concordance, they confirmed that on a relatively coarse level (e.g., 2 digit), the Schmoch et al. (2003) concordance enable a useful empirical and policy analysis.

8 Since the OECD Indicator of Environmental Technologies (see OECD 2012) is based on the patent classification, each patent is classified at the same time (a) as green or non-green and (b) is assigned to a certain industry class. This allows us to identify for each industry class the total number of green and non-green patents.
} 
Table 1 Number of green and other inventions by industry and country 1980-2009

\begin{tabular}{|c|c|c|c|c|}
\hline & $\begin{array}{l}\text { Number of } \\
\text { other } \\
\text { inventions }\end{array}$ & $\begin{array}{l}\text { Number of } \\
\text { green } \\
\text { inventions }\end{array}$ & $\begin{array}{l}\text { Relative share } \\
\text { in total green } \\
\text { inventions }(\%)\end{array}$ & $\begin{array}{l}\text { Share of green } \\
\text { inventions in total } \\
\text { inventions (\%) }\end{array}$ \\
\hline \multicolumn{5}{|l|}{ Industry } \\
\hline Food, beverages & 37,798 & 1,672 & 0.65 & 4.2 \\
\hline Tobacco products & 2,325 & 69 & 0.03 & 2.9 \\
\hline Textiles & 16,111 & 1,070 & 0.42 & 6.2 \\
\hline Wearing apparel & 5,733 & 75 & 0.03 & 1.3 \\
\hline Leather articles & 3,670 & 19 & 0.01 & 0.5 \\
\hline Wood products & 4,584 & 256 & 0.10 & 5.3 \\
\hline Paper & 21,463 & 1,400 & 0.54 & 6.1 \\
\hline $\begin{array}{l}\text { Petroleum products, } \\
\text { nuclear fuel }\end{array}$ & 17,053 & 3,514 & 1.37 & 17.1 \\
\hline $\begin{array}{l}\text { Rubber and plastics } \\
\text { products }\end{array}$ & 102,022 & 6,485 & 2.52 & 6.0 \\
\hline $\begin{array}{l}\text { Non-metallic mineral } \\
\text { products }\end{array}$ & 81,906 & 8,965 & 3.48 & 9.9 \\
\hline Basic metals & 42,426 & 6,892 & 2.68 & 14.0 \\
\hline Fabricated metal products & 61,777 & 8,073 & 3.14 & 11.6 \\
\hline Machinery & 421,085 & 61,667 & 23.96 & 12.8 \\
\hline $\begin{array}{l}\text { Office machinery and } \\
\text { computers }\end{array}$ & 271,075 & 5,276 & 2.05 & 1.9 \\
\hline $\begin{array}{l}\text { Electrical machinery } \\
\text { and apparatus }\end{array}$ & 96,389 & 28,502 & 11.08 & 22.8 \\
\hline $\begin{array}{l}\text { Radio, television and } \\
\text { communication } \\
\text { equipment }\end{array}$ & 416,041 & 23,731 & 9.22 & 5.4 \\
\hline $\begin{array}{l}\text { Medical, precision } \\
\text { and optical } \\
\text { instruments }\end{array}$ & 464,886 & 14,898 & 5.79 & 3.1 \\
\hline Motor vehicles & 90,872 & 29,911 & 11.62 & 24.8 \\
\hline $\begin{array}{l}\text { Other transport } \\
\text { equipment }\end{array}$ & 25,742 & 2,495 & 0.97 & 8.8 \\
\hline $\begin{array}{l}\text { Furniture, consumer } \\
\text { goods }\end{array}$ & 47,174 & 561 & 0.22 & 1.2 \\
\hline $\begin{array}{l}\text { Chemicals } \\
\text { (excluding phar- } \\
\text { maceuticals) }\end{array}$ & 301,064 & 46,427 & 18.04 & 13.4 \\
\hline Pharmaceuticals & 322,450 & 5,382 & 2.09 & 1.6 \\
\hline \multicolumn{5}{|l|}{ Country } \\
\hline Austria & 30,593 & 3,311 & 1.29 & 9.8 \\
\hline Switzerland & 93,498 & 5,720 & 2.22 & 5.8 \\
\hline Germany & 414,160 & 49,795 & 19.35 & 10.7 \\
\hline Denmark & 30,970 & 3,825 & 1.49 & 11.0 \\
\hline Finland & 43,313 & 3,004 & 1.17 & 6.5 \\
\hline France & 167,953 & 14,723 & 5.72 & 8.1 \\
\hline United Kingdom & 194,920 & 14,829 & 5.76 & 7.1 \\
\hline Italy & 58,198 & 4,314 & 1.68 & 6.9 \\
\hline
\end{tabular}


Table 1 continued

\begin{tabular}{lllll}
\hline & $\begin{array}{l}\text { Number of } \\
\text { other } \\
\text { inventions }\end{array}$ & $\begin{array}{l}\text { Number of } \\
\text { green } \\
\text { inventions }\end{array}$ & $\begin{array}{l}\text { Relative share } \\
\text { in total green } \\
\text { inventions }(\%)\end{array}$ & $\begin{array}{l}\text { Share of green } \\
\text { inventions in total } \\
\text { inventions }(\%)\end{array}$ \\
\hline Japan & 490,415 & 59,595 & 23.16 & 10.8 \\
Netherlands & 116,486 & 9,306 & 3.62 & 7.4 \\
Sweden & 93,741 & 6,397 & 2.49 & 6.4 \\
United States & $1,119,399$ & 82,521 & 32.07 & 6.9 \\
\hline
\end{tabular}

These statistics are based on 30 cross-sections, 12 countries and 22 industries (total of 7,920 observations); the relative share in total green inventions is calculated as the share of an industry's/country's number of green inventions relative to the number of all green inventions in our sample (sum of green inventions over all industries/countries in the sample); the share of green inventions in total inventions is defined as an industry's/ country's share of green inventions relative to its total number of inventions (green inventions and other inventions)

Among the twelve countries that are in our sample, the United States (32\%), Japan (23\%) and Germany $(19 \%)$ have the highest number of green inventions. Japan and Germany have also high shares of green inventions. The highest shares, however, can be found in Denmark, whereby green inventions represent $11 \%$ of all inventions in this country.

To analyse the impact of green inventions on performance, further information on the output, labour input and capital stock of the industries is required. Information for all three variables comes from the OECD STAN database (OECD 2011).

\section{Empirical Framework}

To analyse the impact of green inventions on performance, we augment a standard production function with a variable that measures an industry's stock in green inventions (Green_stock; see, e.g., Bloom and Reenen 2002 or Guellec and Pottelsberghe 2004 for a related approach). Following Cockburn and Griliches (1988) and Aghion et al. (2012), the invention stock is calculated using the perpetual inventory method. Following this method, the stock is defined as

$$
\text { Green_stock }_{i j t}=(1-\delta) \text { Green_stock } k_{i j t-1}+\text { Green_inventions } s_{i j t} \text {, }
$$

where $\delta$ is the depreciation rate of R\&D capital. ${ }^{9}$ According to most of the literature, we take $\delta$ to be equal to $15 \%$ (see Keller 2002; Aghion et al. 2012). However, we test the sensitivity of our results against other depreciation rates (see Table 10) as well.

We deduce from a negative relationship between the industries' stock of green inventions (Green_stock) and performance that costs are considerably higher than the benefits from investing in green research. Following R1 we thus analyse whether Green_stock is positively related to performance.

R2 indicates increasing 'scale effects' and hence learning from green invention activities in terms of performance should be detected. Accordingly, R2 points at a non-linear relationship between Green_stock and performance. To identify such non-linear relationships, we

\footnotetext{
9 The initial value of the invention stock was set at Green_stock $1980 /(\delta+g)$, where $g$ is the pre-1980 growth in invention stock. In line with Aghion et al. (2012) we assumed $g$ to be $15 \%$. However, as the number of green inventions in 1980 was very limited (see Fig. 2), the impact of $g$ was small. To test the robustness of our results, we reduced the influence of the initial stock by increasing the lag between the estimation period and the initial stock (see Table 4 for alternative estimates).
} 
additionally include a quadratic term of Green_stock in our model. ${ }^{10}$ In addressing R2, we expect the effect of the quadratic term Green_stock ${ }^{2}$ to be positive.

The augmented specification for a country $i$ and an industry $j$ at time $t$ is given by:

$$
\begin{aligned}
\ln (q)_{i j t}= & \ln (A)+\alpha \ln \left(L_{i j t}\right)+\beta \ln \left(K_{i j t}\right)+\phi_{1} \text { Green_stock_dijt-1} \\
& +\phi_{2} \text { Green_stock } k_{i j t-1}+\phi_{3} \text { Green_stock }{ }_{i j t-1}^{2} \\
& +\lambda_{1} \text { Other_stock } k_{i j t-1}+\lambda_{2} \text { Other_stock }{ }_{i j t-1}^{2}+\mu Y e a r_{t}+\eta_{i j}+\varepsilon_{i j t},
\end{aligned}
$$

where $q$ is the output, $L$ is the labour input, $K$ the capital stock and $A$ is a constant. In our model, we use the industries' total value added in real terms as a proxy for output $(q)$. The total number of employees engaged proxies labour $(L)$ and the gross fixed capital formation in real terms is used to proxy physical capital $(K)$. Ideally, one would use data on the capital stock instead of capital formation. Unfortunately, these data are only available for a few countries in the STAN database. We thus use a flow variable as a proxy for physical capital. Both variables, $L$ and $K$, should be positively related with value added.

Green inventions are expected to be strongly linked to the industries' general invention potentials and their invention affinities. Accordingly, not controlling for invention activities in non-green technologies would bias our results. To deal with this issue, we add controls for the stock of inventions within an industry that are not classified as green (Other_stock). The stock of other inventions is calculated in the same way as the stock of green inventions.

All variables dealing with inventions are not in logarithmic form, since there are a substantial number of industries with zero values (see Wooldridge 2009, p. 185). This number is substantial especially with respect to the stock of green inventions (about $20 \%$ of the observations in the whole sample; about $15 \%$ in the estimates). The large share also indicates that the effect of a switch from no green stock to a certain green stock may be relevant with respect to the performance, which is, however, not captured by the linear terms. To capture econometric effects of these zero values, we thus include a dummy variable that measures whether there are green inventions within an industry (Green_stock_d).

The invention variables are introduced with a lag of 1 year to deal with the potential problem of reverse causality. To control for correlated unobserved heterogeneity, we include country-specific industry fixed effects $\left(\eta_{i j}\right)$ and year fixed effects (Year) (see Table 2 for variable description). Furthermore, to make sure that our results are not affected by an omitted variable bias we control in alternative estimates for country-specific time fixed effects (see Table 9). These variables should capture effects driven by country specific shocks such as changes in a country's environmental regulation system.

\section{Estimation Results}

\subsection{Main Results}

The estimation results are reported in Table 3. The main results are presented in column (1). To test the robustness of this model, columns (2) and (3) show the same model as in column (1) with some modifications. In column (2) the model is estimated for a shorter time period ('early stage'). Column (3) does not include the physical capital variable. In this way, we test

10 The robustness of our results with respect to alternative model specifications (e.g., no quadratic terms) is tested in alternative estimates (see Table 7). 
Table 2 Variable definition and measurement

\begin{tabular}{lll}
\hline Variable & Definition/measurement & Source \\
\hline $\begin{array}{l}\text { Dependent variable } \\
\mathrm{q}\end{array}$ & Value added, volumes (current price value) & OECD STAN \\
Independent variable & & \\
$\mathrm{L}$ & Number of persons engaged (total employment) & OECD STAN \\
$\mathrm{K}$ & Gross fixed capital formation, volumes (current price value) & OECD STAN \\
Other_inventions & Number of inventions that are not classified as green & Own calculations \\
Green_inventions & Number of green inventions & Own calculations \\
Other_stock & Stock of inventions that are not classified as green & Own calculations \\
Green_stock & Stock of green inventions & Own calculations \\
\hline
\end{tabular}

the robustness of our results for a considerably larger sample, since our proxy for the physical capital has many missing values (e.g., no information for Japan and Switzerland). For most models, $F$ test and Hausman-test show that OLS and random-effects GLS, respectively, are not appropriate methods for estimating our production function. We thus conclude that fixed-effects regression is the appropriate method to deal with unobserved heterogeneity in our model. The model of column (3) is an exception. In column (4) we thus alternatively use random-effects GLS to estimate this model. However, the results are very similar.

Green inventions do significantly affect value added. While the coefficient of Green_stock is negative, the coefficient of the quadratic term Green_stock ${ }^{2}$ is positive. The relationship between value added and green inventions is U-shaped. Thus hypotheses 1 and 2 are confirmed. Furthermore, a shift from an industry without green inventions to an industry with green inventions (Green_stock_d) positively affects the value added of the industry. This effect is just not statistically significant at the $10 \%$ test level in our main model ( $t$ value $=1.50)$, but it becomes statistically significant when we analyse the impact for the early stage separately (see column 2). In the period 1981-2001, a switch from zero to a certain level of green invention stock increases the value added by about $11 \%$. Accordingly, additional revenues of green invention exceed its additional costs at low levels of invention activities. This effect may be interpreted as a kind of advertising (image) effect. Industries that start to innovate in green technologies obtain a green touch, which positively stimulates performance. Costs are under such circumstances comparatively low, as invention activities are kept at moderate levels. As time passes, fewer industries without any green invention stock can be observed and, accordingly, the advertising (image) effect from a switch to green inventions disappears.

While the effect of a switch to green inventions is positive (Green_stock_d), the total effect of green inventions (combination of the effects of all Green_stock variables) rapidly decreases with additional innovation activities (Green_stock). At low stocks of green inventions, the positive switching effect to green inventions dominates and thus a positive overall effect of green invention results. An increasing stock of green inventions reduces the impact of this switching effect, and the overall effect turns negative. Over the whole sample period, the industries' green stocks increased on average by 16 inventions per year. Given the marginal effects in Table 3 (column 1), an increase of the sample average (152 inventions) by 16 inventions would decrease the value added by about $2 \%$.

The marginal effect of green inventions increases with additional green inventions. Thus, industries with a higher knowledge stock in green inventions have in general lower investment costs for the same amount of invention output. The increasing negative marginal effect of 
Table 3 Estimates of the production function

\begin{tabular}{|c|c|c|c|c|c|}
\hline \multirow[b]{2}{*}{$\begin{array}{l}\text { Period } \\
\text { Estimation } \\
\text { method }\end{array}$} & \multicolumn{5}{|l|}{$\ln \left(\mathrm{q}_{\mathrm{ijt}}\right)$} \\
\hline & $\begin{array}{l}(1) \\
1981-2009 \\
\text { Fixed-effects } \\
\text { regression }\end{array}$ & $\begin{array}{l}(2) \\
1981-2001 \\
\text { Fixed-effects } \\
\text { regression }\end{array}$ & $\begin{array}{l}(3) \\
1981-2009 \\
\text { Fixed-effects } \\
\text { regression }\end{array}$ & $\begin{array}{l}\text { (4) } \\
\text { 1981-2009 } \\
\text { Random-effects } \\
\text { GLS }\end{array}$ & $\begin{array}{l}(5) \\
1981-2009 \\
\text { OLS }\end{array}$ \\
\hline Constant $_{i j t}$ & $\begin{array}{l}9.6274 * * * \\
(2.0202)\end{array}$ & $\begin{array}{l}10.337 * * * \\
(1.823)\end{array}$ & $\begin{array}{l}12.011^{* * *} \\
(1.594)\end{array}$ & $\begin{array}{l}11.388 * * * \\
(1.1122)\end{array}$ & $\begin{array}{l}8.6915 * * * \\
(.67654)\end{array}$ \\
\hline $\ln \left(\mathrm{L}_{\mathrm{ijt}}\right)$ & $\begin{array}{l}.89323 * * * \\
(.16859)\end{array}$ & $\begin{array}{l}.93892 * * * \\
(.1388)\end{array}$ & $\begin{array}{l}.9177 * * * \\
(.1442)\end{array}$ & $\begin{array}{l}.94631 * * * \\
(.11356)\end{array}$ & $\begin{array}{l}.75092 * * * \\
(.07075)\end{array}$ \\
\hline $\ln \left(\mathrm{K}_{\mathrm{ijt}}\right)$ & $\begin{array}{l}.11018 \\
(.07014)\end{array}$ & $\begin{array}{l}.04791 \\
(.05102)\end{array}$ & & & $\begin{array}{l}.24552 * * * \\
(.05509)\end{array}$ \\
\hline Other_stock $\mathrm{ijt}_{\mathrm{ij}} 1$ & $\begin{array}{l}.0002 * * \\
(9.7 \mathrm{e}-05)\end{array}$ & $\begin{array}{l}.00023 * \\
(.00012)\end{array}$ & $\begin{array}{l}.00016 * * \\
(6.5 \mathrm{e}-05)\end{array}$ & $\begin{array}{l}.00015 * * \\
(6.3 \mathrm{e}-05)\end{array}$ & $\begin{array}{l}.00014 * * \\
(6.8 \mathrm{e}-05)\end{array}$ \\
\hline Other_stock ${ }_{\mathrm{ijt}-1}^{2}$ & $\begin{array}{l}-5.1 \mathrm{e}-09^{* *} \\
(2.5 \mathrm{e}-09)\end{array}$ & $\begin{array}{l}-1.1 \mathrm{e}-08^{*} \\
(5.9 \mathrm{e}-09)\end{array}$ & $\begin{array}{l}-3.6 \mathrm{e}-09^{* *} \\
(1.5 \mathrm{e}-09)\end{array}$ & $\begin{array}{l}-3.4 \mathrm{e}-09^{* *} \\
(1.5 \mathrm{e}-09)\end{array}$ & $\begin{array}{l}-4.3 \mathrm{e}-09 * * \\
(2.0 \mathrm{e}-09)\end{array}$ \\
\hline $\begin{array}{l}\text { Green_stock_ } \\
\mathrm{d}_{\mathrm{ijt}-1}\end{array}$ & $\begin{array}{l}.08698 \\
(.05791)\end{array}$ & $\begin{array}{l}.11222 * * \\
(.05507)\end{array}$ & $\begin{array}{l}.09013 \\
(.06584)\end{array}$ & $\begin{array}{l}.09136 \\
(.06616)\end{array}$ & $\begin{array}{l}.10453 \\
(.07103)\end{array}$ \\
\hline Green_stock $\mathrm{ijt}_{\mathrm{ij}} \mathrm{1}$ & $\begin{array}{l}-.00122^{* * *} \\
(.00058)\end{array}$ & $\begin{array}{l}-.00183^{*} \\
(.00093)\end{array}$ & $\begin{array}{l}-.00099 * * \\
(.00041)\end{array}$ & $\begin{array}{l}-.00094 * * \\
(.00039)\end{array}$ & $\begin{array}{l}-.00083^{* *} \\
(.0004)\end{array}$ \\
\hline Green_stock $k_{\mathrm{ijt}-1}^{2}$ & $\begin{array}{l}2.0 e-07 * * \\
(1.0 e-07)\end{array}$ & $\begin{array}{l}5.6 e-07 * \\
(3.2 e-07)\end{array}$ & $\begin{array}{l}1.4 e-07 * * \\
(6.3 e-08)\end{array}$ & $\begin{array}{l}1.4 e-07 * * \\
(6.1 e-08)\end{array}$ & $\begin{array}{l}1.7 e-07 * * \\
(8.1 e-08)\end{array}$ \\
\hline Year FE & Yes & Yes & Yes & Yes & Yes \\
\hline $\begin{array}{l}\text { Country specific } \\
\text { industry FE }\end{array}$ & Yes & Yes & Yes & No & No \\
\hline Industry FE & No & No & No & Yes & Yes \\
\hline Country FE & No & No & No & Yes & Yes \\
\hline $\mathrm{N}$ & 2,936 & 1,969 & 4,527 & 4,527 & 2,936 \\
\hline Groups & 146 & 146 & 201 & 201 & 146 \\
\hline $\mathrm{R}^{2}$ & & & & & 0.97 \\
\hline $\mathrm{R}^{2}$ within & 0.48 & 0.51 & 0.38 & 0.38 & \\
\hline Rho & 0.91 & 0.96 & 0.96 & 0.43 & \\
\hline F test of $\rho=0$ & $41.66 * * *$ & $67.40 * * *$ & $613.77 * * *$ & & \\
\hline $\begin{array}{l}\text { Hausman } \chi^{2} \\
\text { LR test of } \rho=0\end{array}$ & $361.53 * * *$ & $63.90 * * *$ & 19.93 & $\begin{array}{l}19.93 \\
10096^{* * *}\end{array}$ & \\
\hline
\end{tabular}

See Table 2 for the variable definitions; standard errors that are robust to heteroskedasticity and clustered at the industry-country level (clustered sandwich estimator) are in brackets under the coefficients; ***, **, * denote statistical significance at the $1 \%, 5 \%$ and $10 \%$ test level, respectively. F test and Hausman test are based on estimates without robust standard errors 
green inventions on value added turns around at a stock of 3,014 inventions. Beyond this point, the marginal effect of additional green inventions relates positively to value added. Accordingly, we can affirm the second research question. Industries with a large green knowledge stock are more likely to show a positive performance effect from additional green invention than industries with a small green knowledge stock. However, only a few industries have a green stock of more than 3,014 inventions. In our sample, only $1 \%$ of the industries exceed this level. Consequently, the first research question cannot be affirmed. Green innovation activities (independent whether they are policy induced or not) are predominantly negatively linked to performance.

The results for the control variables are on the whole in line with general expectations. Labour input $(L)$ and the stock of other inventions (Other_stock) are both positively correlated with the value added of the industries $(q)$. The impact of Other_stock is inverted-U shapedthe quadratic term is significantly negative. However, as only very few industries in our sample have a stock of other inventions above the turnaround value, the decreasing part of the inverted-U can be ignored. Thus, the marginal effect of other inventions is positive, but it is negatively correlated with very high invention intensity. The impact of physical capital $(K)$ on value added is positive, but just not significant at the $10 \%$ level $(t$ value $=1.57)$. The expected positive effect of physical capital is significant (at the $1 \%$ level) only in the OLS models (see column (5) of Table 3). Thus, a possible reason for the insignificant effect in the fixed-effects model is that the variation of physical capital is low within the industries over time. Corrections for unobserved heterogeneity cancel this effect out.

Information on physical capital in real terms is not available for Japan and Switzerland. Hence, these two countries have not been included in our estimates so far. To test the robustness of our results, we alternatively estimated our model without the physical capital variable. In general, this should not affect our main results, as the effect of physical capital has not been significant in previous estimates. Results are shown in columns (3) and (4) of Table 3. The estimation includes all 12 countries in our sample. Comparing the results in column (4) to those in column (1) shows that the estimates are largely the same.

\subsection{Performance Effects over a Period of Time: Comparing Earlier Periods with Later Periods of Inventions}

The impact of green inventions on performance for the whole sample period is predominantly negative. This indicates that sales markets do not provide sufficient incentives to increase firms' green innovation activities. One reason for this finding may be the long sample period and different performance effects in earlier periods as compared to later periods. Especially in early periods of green inventions, the costs of invention were relatively greater and, at the same time, the demand for green inventions was limited. The marginal costs of green inventions should have decreased over time. Furthermore, increasing political pressure may also have stimulated the demand for such inventions in the recent years. We thus expect that the negative impact of green inventions on performance has declined over time.

To analyse such time-varying effects, we estimated our main model separately for four different time segments. Estimation results are presented in Table 4. Due to a limited number of observations, especially in early periods of green inventions, it is not possible to estimate models without overlapping time segments. Consequently, we estimated the model for overlapping time segments. From one column to the next, we shortened the time segment by 5 years. Accordingly, the impact of the last years in a time segment increases from one estimate to the next. 
Table 4 Analysis for different time segments (fixed-effects regressions)

\begin{tabular}{|c|c|c|c|c|}
\hline \multirow[b]{2}{*}{ Period } & \multicolumn{4}{|l|}{$\ln \left(q_{i j t}\right)$} \\
\hline & $\begin{array}{l}(1) \\
1983-2009\end{array}$ & $\begin{array}{l}(2) \\
1989-2009\end{array}$ & $\begin{array}{l}(3) \\
1994-2009\end{array}$ & $\begin{array}{l}(4) \\
1999-2009\end{array}$ \\
\hline Constant & $\begin{array}{l}10.12 * * * \\
(2.0414)\end{array}$ & $\begin{array}{l}11.083 * * * \\
(2.0964)\end{array}$ & $\begin{array}{l}12.4 * * * \\
(1.9348)\end{array}$ & $\begin{array}{l}13.69 * * * \\
(2.9622)\end{array}$ \\
\hline $\ln \left(\mathrm{L}_{\mathrm{ijt}}\right)$ & $\begin{array}{l}.86564 * * * \\
(.17596)\end{array}$ & $\begin{array}{l}.79342 * * * \\
(.18623)\end{array}$ & $\begin{array}{l}.74074 * * * \\
(.18152)\end{array}$ & $\begin{array}{l}.66803 * * \\
(.33648)\end{array}$ \\
\hline $\ln \left(\mathrm{K}_{\mathrm{ijt}}\right)$ & $\begin{array}{l}.10725 \\
(.06579)\end{array}$ & $\begin{array}{l}.11037 * \\
(.05814)\end{array}$ & $\begin{array}{l}.086 * * \\
(.04202)\end{array}$ & $\begin{array}{l}.06117 \\
(.06401)\end{array}$ \\
\hline Other_stock $\mathrm{ijt}_{\mathrm{ij}-1}$ & $\begin{array}{l}.0002 * * \\
(9.6 \mathrm{e}-05)\end{array}$ & $\begin{array}{l}.0002 * * \\
(9.5 \mathrm{e}-05)\end{array}$ & $\begin{array}{l}.0002 * * \\
(8.5 \mathrm{e}-05)\end{array}$ & $\begin{array}{l}.00017 * * \\
(7.0 \mathrm{e}-05)\end{array}$ \\
\hline Other_stock $\mathrm{ijt}-1^{2}$ & $\begin{array}{l}-5.0 \mathrm{e}-09 * * \\
(2.4 \mathrm{e}-09)\end{array}$ & $\begin{array}{l}-4.9 \mathrm{e}-09^{* *} \\
(2.4 \mathrm{e}-09)\end{array}$ & $\begin{array}{l}-4.4 \mathrm{e}-09^{* *} \\
(2.0 \mathrm{e}-09)\end{array}$ & $\begin{array}{l}-3.2 \mathrm{e}-09 * * \\
(1.5 \mathrm{e}-09)\end{array}$ \\
\hline Green_stock_d $\mathrm{d}_{\mathrm{ijt}-1}$ & $\begin{array}{l}.04792 \\
(.06068)\end{array}$ & $\begin{array}{l}-.04616 \\
(.08359)\end{array}$ & $\begin{array}{l}-.0948 \\
(.0896)\end{array}$ & $\begin{array}{l}-.05042 \\
(.09283)\end{array}$ \\
\hline Green_stock $\mathrm{ijt}_{\mathrm{i}-1}$ & $\begin{array}{l}-.00123^{* *} \\
(.00057)\end{array}$ & $\begin{array}{l}-.00122 * * \\
(.00056)\end{array}$ & $\begin{array}{l}-.00111^{* *} \\
(.0005)\end{array}$ & $\begin{array}{l}-.00085^{* *} \\
(.00043)\end{array}$ \\
\hline Green_stock ${ }_{\mathrm{ijt}-1}^{2}$ & $\begin{array}{l}2.0 e-07 * * \\
(9.9 e-08)\end{array}$ & $\begin{array}{l}2.0 e-07 * * \\
(9.5 e-08)\end{array}$ & $\begin{array}{c}1.7 e-07 * * \\
(8.0 e-08)\end{array}$ & $\begin{array}{l}1.1 e-07 * \\
(6.1 e-08)\end{array}$ \\
\hline Year FE & Yes & Yes & Yes & Yes \\
\hline $\begin{array}{l}\text { Country-specific } \\
\text { industry FE }\end{array}$ & Yes & Yes & Yes & Yes \\
\hline $\mathrm{N}$ & 2,756 & 2,446 & 2,018 & 1,401 \\
\hline Groups & 146 & 146 & 146 & 146 \\
\hline $\mathrm{R}^{2}$ within & 0.45 & 0.40 & 0.34 & 0.26 \\
\hline Rho & 0.92 & 0.91 & 0.93 & 0.95 \\
\hline
\end{tabular}

See Table 2 for the variable definitions; standard errors that are robust to heteroskedasticity and clustered at the industry-country level (clustered sandwich estimator) are in brackets under the coefficients; $* * *, * *, *$ denote statistical significance at the $1 \%, 5 \%$ and $10 \%$ test level, respectively

Because the first years were disregarded, we found that the switching effect (Green stock_d) is not statistically different from zero for all four time segments, which is in line with our previous result in Table 3 (column 1). As expected, the estimation results show that the negative impact of green inventions decreases over time. Figure 3 shows the marginal effect of green inventions for the four different time segments. ${ }^{11}$ While the marginal effect for the first two time segments is almost the same, we found that the negative marginal effect of green inventions decreases over time. Furthermore, the decrease seems to accelerate over

11 As can be seen in Fig. 2, the number of green inventions steadily increased over time. Accordingly, average green invention stocks also increased from one time window to the next. In line with this trend also the turning points slightly increased over time (turning point 1983-2009: 3,051; turning point 1989-2000: 3,116; turning point 1994-2000: 3,289; turning point 1999-2009: 3,813). As both trends go in the same direction, the turning points are, however, of low relevance. In each time window less than $1.5 \%$ of the observations exceed these levels. Accordingly, we decided to refrain from interpreting the turning points and instead focus on the marginal effects of additional Green stock up to 1,400 only (in each time window less than $5 \%$ of the observations exceed this level). 


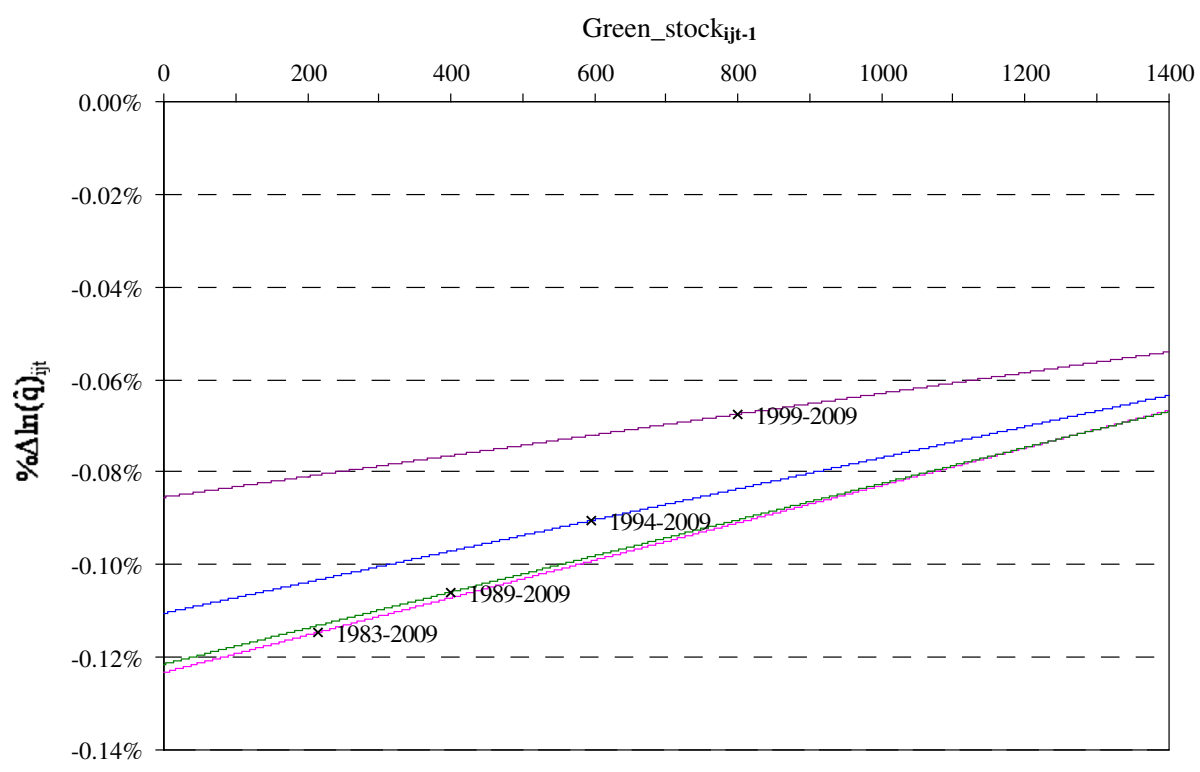

Fig. 3 Marginal effect of additional Green_stock for different time windows ( $\Delta$ Green_stock=1). Notes This figure is plotted for values of Green_stock between 0 and 1,400 only because in each time window less than $5 \%$ of the observations have a higher Green_stock

time. However, there is still a statistically significant negative impact of green inventions on value added for most industries, even in the last period of observation (1999-2009).

\subsection{Robustness Tests}

We made comprehensive tests to check the robustness of our main results presented in column (1) of Table 3.

\subsubsection{Alternative Model Specifications}

Table 7 shows the robustness of our results with respect to alternative model specifications. Column (1) shows the results for the standard production function. The model in column (2) additionally includes the linear terms of the invention variables. Column (3) adds the dummy variable that captures the effect of zero values. Column (4) shows the results for the model that includes the non-linear terms of the invention variables but not the correction for zero values. The results of our main model are presented in column (5). The estimates show that our results do only marginally change between model specifications. While the impact of non-green invention tends to be positive, the effect of green invention is negative. Furthermore, the estimates show that the significance of the invention variables increases when we include the non-linear terms. Accordingly, we conclude that our main model that includes the quadratic form is the model that best fit the data.

\subsubsection{Flow of Inventions Instead of Stock}

Table 8 shows an alternative estimate of the model that includes the flow of inventions instead of the stock variables. These alternative estimates of green inventions only marginally affect 
our results. Again, the impact of green inventions is U-shaped and only very few industries have positive returns from additional green inventions. However, in contrast to our previous results, there is now a statistically significant positive switching effect (Green_invention_d) for the whole sample period. A reason for this result seems to be that Green_invention_d is more likely to vary across time, since one may have green inventions in one period and zero inventions in the following period. In contrast, the Green_stock of an industry may be larger than zero, even if the industry has no green inventions in a certain period. Nevertheless, it is worth noting that the size of the impact of the switching effect is comparable to what we found in our previous estimates.

\subsubsection{Controlling for Country-Specific Time Effects}

All our estimates include annual fixed effects, aiming to control for the impact of global shocks. However, we have no control for country-specific shocks. For example, changing political influence within a certain country may affect the demand for green products over time. As this would directly affect performance, the impact of our measure for green inventions may be biased. To control for such effects, we estimated our main model including country-specific time effects. The results of this estimation are presented in column (1) of Table 9. Here we see that country-specific time effects only have a marginal impact on our results. The effect of the intensity of Green_stock is nearly the same. However, some differences can be observed for the switching effect. While the impact of Green_stock_d was just not significant in our main model, it is significantly positive now.

\subsubsection{Alternative Lags}

Another problem may be that the impact of green inventions on performance has a certain time lag. This problem is even more pronounced when invention waves are observed. As we analysed the impact of green inventions on an aggregated level, the impact of invention waves should be reduced. To further control for this problem, we alternatively estimated our main model using larger lags. Estimation results for a 2-year lag and a 5-year lag respectively are presented in column (2) and (3) of Table 9. Our main results are robust to such modifications. The differences are the same as when we estimate our model for different time segments (see column (2) of Table 3). As mentioned above, the meaning of the switching effect is greater if green stocks are relatively lower. Since this is observable in earlier times of green inventions and longer lags emphasize earlier periods, we expect a larger switching effect when introducing further lags in our model. Accordingly, it is not surprising to see in our estimations with larger lags a significantly positive switching effect. However, the impact of additional green inventions on value added is still negative for most industries.

\subsubsection{Checking for Outliers}

Column (4) of Table 9 shows the estimation result with regard to outliers. The distribution of inventions across industries is highly heterogeneous. For this reason, we disregarded the top $1 \%$ of the individual industries in both clean and dirty invention stocks. ${ }^{12}$ This only marginally affected our results. We thus conclude that our results are not driven by outliers.

12 Our main estimates presented in column (1) of Table 3 are based on 146 groups. To check for outliers, we excluded all groups with an average clean or dirty invention stock greater THAN or equal to the top $1 \%$ of the groups. All in all, we thus dropped two groups that account for $1.6 \%$ of the observations. 


\subsubsection{Alternative Construction of the Invention Stocks}

In literature, different ways of constructing an invention stock are described (see Keller 2002; Aghion et al. 2012; Cockburn and Griliches 1988). The level of the depreciation rate, as well as the construction of the initial stock, may affect estimation results. Regression results for alternative ways of constructing the invention stocks are presented in Table 10; columns (1) and (2) show the estimates for alternative depreciation rates. Such modifications do not affect our main results. As we have seen in previous estimates, our main results are also valid in the case of higher depreciation rates (invention flows $\rightarrow \delta=100 \%$ ).

The influence of the initial green stock on regression decreases with an increasing lag between regression period and initial stock. As we have seen in Table 4, the results are robust for different time segments, which indicates that the impact of the initial stock on our main results is negligible.

\section{Conclusions}

In this paper, the impact of green inventions on performance was analysed. Addressing this issue is an important task. On the one hand, the need for green inventions steadily increases. On the other hand, the incentives for firms to invest in green inventions primarily depend on the performance effect of such inventions. If green innovation activities turn out to be profitable, further policy interventions would be unnecessary.

The relationship between green inventions and performance was analysed on the basis of industry-level data that include most manufacturing industries, the most relevant countries for green inventions and a time period of 30 years. We found a positive effect of switching to green inventions for earlier years of observation. However, the general relationship between the intensity of green inventions and performance is U-shaped; for most industries, an increasing level of green inventions negatively affects performance. With a value of 3,014 inventions, the turning point is considerably high. Only industries with a very large stock of green inventions are likely to show a positive effect on their performance. These results are robust for different time segments. As expected, we saw strong negative marginal effects in early periods and, even in the last period of our sample, the marginal effect of green inventions on performance remained negative for most industries, but to a smaller extent. Consequently, we can answer Popp's (2005, p. 224) question as to whether environmentally friendly inventions will proceed without policy adjustments with probably no.

Since the impact of green invention is negative, why do we observe firms that invest in green invention when they alternatively could invest in more profitable non-green technologies? To answer this question we made several interviews with multinational enterprises that have a good understanding of what happens on the global market of green invention. ${ }^{13}$ These firms mentioned essentially two reasons. Firstly, green invention is required to maintain market shares, as customers in existing markets demand green invention (e.g., as new regulations force them to adjust their products), but due to intensive competition, the firms cannot transfer the additional costs for green invention to their customers.

Secondly, green invention is seen as an investment in future markets. Firms try to patent technological advances in time in order to benefit, e.g. through royalties, from further research

\footnotetext{
13 Overall, we made interviews with employees of three different globally active firms operating in the chemical industry, power and automation technology areas and power generation and transportation markets, respectively. To get a representative picture, the head of the R\&D department as well as employees responsible for specific environmental technologies were interviewed. The employees were explicitly asked to express not only their own view but also the view of the whole industry they belong to.
} 
that is based on such early key findings. Since inventions in green technologies are a very complex task, it is possible that firms patent for a longer period in time without any technological breakthrough. We have seen such tendencies in some green technologies, like fuel cells or battery technologies for electric cars. This indicates that technological risks are considerable. Moreover, the demand for green inventions is very volatile due to the strong dependency on political issues. Hence, firms are often forced to stop their activities before they can bring the products on the markets. This point is especially true for small firms that are not able to diversify across technologies, markets, or regions. On the industry level we can thus often observe inventions without market success. The interviews also confirmed the low willingness to pay for green products, since very often the customers do not exclusively benefit from such inventions. Accordingly, returns are often low, even when firms are able to market their technologies.

These results are of significant policy relevance. Technological inventions are needed to solve environmental problems. "Without significant technological development of both existing low-carbon technologies and new ones, climate change is unlikely to be limited to anything like $2^{\circ} \mathrm{C}$ by 2050" (see Helm 2012, p. 213). As we cannot explicitly capture the effect of environmental policies in our framework, the negative overall effect of green inventions may either be driven by a direct negative effect of green inventions or an indirect negative effect of induced inventions. In any case, it is important to see that the current policy framework is not sufficient to render environmentally friendly inventions profitable. Our results indicate that more attractive market conditions are required to effectively turn on the private green innovation machine.

Acknowledgments We thank the Editor and two anonymous reviewers of this journal for their valuable comments and suggestions. Moreover, we benefited from discussions with the participants at the Patent Statistics for Decision Makers Conference 2012 in Paris, at the IIOC 2012 in Arlington, at the research seminar in Innsbruck (April 2012), and at the 37th IAEE International Conference 2014 in New York City. We gratefully acknowledge financial support from the MTEC Foundation in Switzerland.

\section{Appendix}

See Appendix Tables 5, 6, 7, 8, 9, 10.

Table 5 Correlation matrix (based on model (1) of Table 3; 2,936 observations)

\begin{tabular}{|c|c|c|c|c|c|c|c|}
\hline & $\ln \left(\mathrm{q}_{\mathrm{ijt}}\right)$ & $\ln \left(\mathrm{L}_{\mathrm{ijt}}\right)$ & $\ln \left(\mathrm{K}_{\mathrm{ijt}}\right)$ & Other_stock $\mathrm{ijt}_{-1}$ & Other_stock $\mathrm{ijt}-1^{2}$ & Green_stock_d $\mathrm{d}_{\mathrm{ijt}-1}$ & Green_stock $\mathrm{ijt}_{\mathrm{j}-1}$ \\
\hline $\ln \left(\mathrm{L}_{\mathrm{ijt}}\right)$ & 0.83 & & & & & & \\
\hline $\ln \left(\mathrm{K}_{\mathrm{ijt}}\right)$ & 0.95 & 0.79 & & & & & \\
\hline Other_stock $\mathrm{ijt}_{\mathrm{ijt}}$ & 0.38 & 0.36 & 0.33 & & & & \\
\hline Other_stock $\mathrm{ijt}-1^{2}$ & 0.17 & 0.17 & 0.16 & 0.86 & & & \\
\hline Green_stock_d $\mathrm{d}_{\mathrm{ijt}-1}$ & 0.43 & 0.32 & 0.44 & 0.15 & 0.05 & & \\
\hline Green_stock $_{\mathrm{ijt}-1}$ & 0.36 & 0.35 & 0.33 & 0.90 & 0.81 & 0.12 & \\
\hline Green_stock $\mathrm{ijt}-1^{2}$ & 0.18 & 0.18 & 0.17 & 0.81 & 0.95 & 0.05 & 0.88 \\
\hline
\end{tabular}


Table 6 Descriptive statistics (based on model (1) of Table 3; 2,936 observations)

\begin{tabular}{|c|c|c|c|c|}
\hline Variable & Mean & Std. Dev. & Min & $\operatorname{Max}$ \\
\hline \multicolumn{5}{|l|}{ Dependent variable } \\
\hline $\ln \left(\mathrm{q}_{\mathrm{ijt}}\right)$ & 21.98 & 1.82 & 15.20 & 25.75 \\
\hline \multicolumn{5}{|l|}{ Independent variable } \\
\hline $\ln \left(\mathrm{L}_{\mathrm{ijt}}\right)$ & 10.75 & 1.76 & 5.72 & 14.46 \\
\hline $\ln \left(\mathrm{K}_{\mathrm{ijt}}\right)$ & 19.97 & 1.93 & 4.61 & 23.89 \\
\hline Other_stock $\mathrm{ijt}_{\mathrm{j}-1}$ & $1,189.14$ & $3,550.93$ & 0 & $54,430.81$ \\
\hline Green_stock_d $\mathrm{d}_{\mathrm{ijt}-1}$ & 0.83 & 0.37 & 0 & 1 \\
\hline Green_stock $k_{\mathrm{ijt}-1}$ & 152.28 & 550.89 & 0 & $8,492.57$ \\
\hline
\end{tabular}

Table 7 Estimate for alternative model specifications (fixed-effects regressions for time window 1981-2009)

\begin{tabular}{|c|c|c|c|c|c|}
\hline \multirow[b]{2}{*}{ Period } & \multicolumn{5}{|l|}{$\ln \left(\mathrm{q}_{\mathrm{ijt}}\right)$} \\
\hline & $\begin{array}{l}\text { (1) } \\
1981-2009\end{array}$ & $\begin{array}{l}(2) \\
1981-2009\end{array}$ & $\begin{array}{l}(3) \\
1981-2009\end{array}$ & $\begin{array}{l}(4) \\
1981-2009\end{array}$ & $\begin{array}{l}(5) \\
1981-2009\end{array}$ \\
\hline Constant & $\begin{array}{l}9.2229 * * * \\
(2.4432)\end{array}$ & $\begin{array}{l}9.3893 * * * \\
(2.3212)\end{array}$ & $\begin{array}{l}9.2933^{* * *} \\
(2.3129)\end{array}$ & $\begin{array}{l}9.7353 * * * \\
(2.0369)\end{array}$ & $\begin{array}{l}9.6274 * * * \\
(2.0202)\end{array}$ \\
\hline $\ln \left(\mathrm{L}_{\mathrm{ijt}}\right)$ & $\begin{array}{l}.94753 * * * \\
(.20337)\end{array}$ & $\begin{array}{l}.92884 * * * \\
(.19147)\end{array}$ & $\begin{array}{l}.93666^{* * * *} \\
(.19264)\end{array}$ & $\begin{array}{l}.8848 * * * \\
(.16787)\end{array}$ & $\begin{array}{l}.89323 * * * \\
(.16859)\end{array}$ \\
\hline $\ln \left(\mathrm{K}_{\mathrm{ijt}}\right)$ & $\begin{array}{l}.10269 \\
(.06882)\end{array}$ & $\begin{array}{l}.10439 \\
(.06965)\end{array}$ & $\begin{array}{l}.10384 \\
(.06899)\end{array}$ & $\begin{array}{l}.11077 \\
(.07099)\end{array}$ & $\begin{array}{l}.11018 \\
(.07014)\end{array}$ \\
\hline Other_stock $\mathrm{ijt}_{\mathrm{ijt}}$ & & $\begin{array}{l}4.8 \mathrm{e}-05 \\
(3.4 \mathrm{e}-05)\end{array}$ & $\begin{array}{l}4.9 \mathrm{e}-05 \\
(3.4 \mathrm{e}-05)\end{array}$ & $\begin{array}{l}.00019 * * \\
(9.7 \mathrm{e}-05)\end{array}$ & $\begin{array}{l}.0002 * * \\
(9.7 \mathrm{e}-05)\end{array}$ \\
\hline Other_stock $\mathrm{ijt}^{2}-1$ & & & & $\begin{array}{l}-5.0 \mathrm{e}-09^{* *} \\
(2.5 \mathrm{e}-09)\end{array}$ & $\begin{array}{l}-5.1 \mathrm{e}-09^{* *} \\
(2.5 \mathrm{e}-09)\end{array}$ \\
\hline Green_stock_d $\mathrm{d}_{\mathrm{ijt}-1}$ & & & $\begin{array}{l}.06898 \\
(.0594)\end{array}$ & & $\begin{array}{l}.08698 \\
(.05791)\end{array}$ \\
\hline Green_stock $_{\mathrm{ijt}-1}$ & & $\begin{array}{l}-.00033^{*} \\
(.0002)\end{array}$ & $\begin{array}{l}-.00033 \\
(.0002)\end{array}$ & $\begin{array}{l}-.00123^{* *} \\
(.00058)\end{array}$ & $\begin{array}{l}-.00122 * * \\
(.00058)\end{array}$ \\
\hline Green_stock $k_{\mathrm{ijt}-1}^{2}$ & & & & $\begin{array}{l}2.0 \mathrm{e}-07 * * \\
(1.0 \mathrm{e}-07)\end{array}$ & $\begin{array}{l}2.0 \mathrm{e}-07 * * \\
(1.0 \mathrm{e}-07)\end{array}$ \\
\hline Year FE & Yes & Yes & Yes & Yes & Yes \\
\hline $\begin{array}{c}\text { Country-specific } \\
\text { industry FE }\end{array}$ & Yes & Yes & Yes & Yes & Yes \\
\hline$N$ & 2,936 & 2,936 & 2,936 & 2,936 & 2,936 \\
\hline Groups & 146 & 146 & 146 & 146 & 146 \\
\hline $\mathrm{R}^{2}$ within & 0.44 & 0.45 & 0.45 & 0.48 & 0.48 \\
\hline Rho & 0.91 & 0.91 & 0.91 & 0.91 & 0.91 \\
\hline
\end{tabular}

See Table 2 for the variable definitions; standard errors that are robust to heteroskedasticity and clustered at the industry-country level (clustered sandwich estimator) are in brackets under the coefficients; ***, **,* denote statistical significance at the $1 \%, 5 \%$ and $10 \%$ test level, respectively 
Table 8 Estimate of the production function based on flows of inventions (fixed-effects regression for time window 1981-2009)

Notes see Table 2 for the variable definitions; standard errors that are robust to heteroskedasticity and clustered at the industry-country level (clustered sandwich estimator) are in brackets under the coefficients; $* * *, * *, *$ denote statistical significance at the $1 \%, 5 \%$ and $10 \%$ test level, respectively

\begin{tabular}{|c|c|}
\hline & $\begin{array}{l}\ln \left(q_{i j t}\right) \\
(1)\end{array}$ \\
\hline Constant & $\begin{array}{l}9.8559 * * * \\
(2.0533)\end{array}$ \\
\hline $\ln \left(\mathrm{L}_{\mathrm{ijt}}\right)$ & $\begin{array}{l}.88 * * * \\
(.17097)\end{array}$ \\
\hline $\ln \left(\mathrm{K}_{\mathrm{ijt}}\right)$ & $\begin{array}{l}.10564 \\
(.06995)\end{array}$ \\
\hline Other_inventions $\mathrm{ijt}_{\mathrm{ijt}} 1$ & $\begin{array}{l}.00071 * \\
(.00039)\end{array}$ \\
\hline Other_inventions $\mathrm{ijt}-1^{2}$ & $\begin{array}{l}-8.0 \mathrm{e}-08 * \\
(4.3 \mathrm{e}-08)\end{array}$ \\
\hline Green_inventions_dijt-1 & $\begin{array}{l}.10338 * * * \\
(.03751)\end{array}$ \\
\hline Green_inventions $\mathrm{ijt}_{\mathrm{ijt}}$-1 & $\begin{array}{l}-.00381 * \\
(.002)\end{array}$ \\
\hline Green_inventions $\mathrm{ijt}-1^{2}$ & $\begin{array}{l}2.7 e-06^{*} \\
(1.5 e-06)\end{array}$ \\
\hline Year FE & Yes \\
\hline Country- specific industry FE & Yes \\
\hline $\mathrm{N}$ & 2,936 \\
\hline Groups & 146 \\
\hline $\mathrm{R}^{2}$ within & 0.48 \\
\hline Rho & 0.91 \\
\hline
\end{tabular}

Table 9 Alternative estimates of model (1) of Table 3 (fixed-effects regressions for time window 1981-2009)

\begin{tabular}{|c|c|c|c|c|}
\hline \multirow[b]{2}{*}{ Robustness test } & \multicolumn{4}{|l|}{$\ln \left(q_{i j t}\right)$} \\
\hline & $\begin{array}{l}\text { (1) } \\
\text { Controlling for } \\
\text { country-specific } \\
\text { time effects }\end{array}$ & $\begin{array}{l}(2) \\
\text { Alternative lags }\end{array}$ & (3) & $\begin{array}{l}\text { (4) } \\
\text { Checking for } \\
\text { outliers }\end{array}$ \\
\hline Constant & $\begin{array}{l}10.451^{* * *} \\
(1.8756)\end{array}$ & $\begin{array}{l}9.7434 * * * \\
(2.0354)\end{array}$ & $\begin{array}{l}9.9895 * * * \\
(2.1372)\end{array}$ & $\begin{array}{l}9.6908 * * * \\
(2.0157)\end{array}$ \\
\hline $\ln \left(\mathrm{L}_{\mathrm{ijt}}\right)$ & $\begin{array}{l}.75307 * * * \\
(.16342)\end{array}$ & $\begin{array}{l}.89216^{* * *} \\
(.172)\end{array}$ & $\begin{array}{l}.87691 * * * \\
(.18082)\end{array}$ & $\begin{array}{l}.88369 * * * \\
(.16899)\end{array}$ \\
\hline $\ln \left(\mathrm{K}_{\mathrm{ijt}}\right)$ & $\begin{array}{l}.1651 * * \\
(.07967)\end{array}$ & $\begin{array}{l}.10537 \\
(.06788)\end{array}$ & $\begin{array}{l}.10857 * \\
(.06132)\end{array}$ & $\begin{array}{l}.11178 \\
(.07077)\end{array}$ \\
\hline Other_stock $\mathrm{ijt}_{-1}$ & $.00026^{* * *}$ & & & $.00021 *$ \\
\hline
\end{tabular}


Table 9 continued

\begin{tabular}{|c|c|c|c|c|}
\hline \multirow[b]{2}{*}{ Robustness test } & \multicolumn{4}{|l|}{$\ln \left(\mathrm{q}_{\mathrm{ijt}}\right)$} \\
\hline & $\begin{array}{l}\text { (1) } \\
\text { Controlling for } \\
\text { country-specific } \\
\text { time effects }\end{array}$ & $\begin{array}{l}(2) \\
\text { Alternative lags }\end{array}$ & (3) & $\begin{array}{l}\text { (4) } \\
\text { Checking for } \\
\text { outliers }\end{array}$ \\
\hline Green_stock_d $\mathrm{d}_{\mathrm{ijt}-1}$ & $\begin{array}{l}.13224 * * \\
(.0552)\end{array}$ & & & $\begin{array}{l}.09437 * \\
(.05638)\end{array}$ \\
\hline Green_stock $\mathrm{ijt}_{-1}$ & $\begin{array}{l}-.00129 * * \\
(.00055)\end{array}$ & & & $\begin{array}{l}-.00118 * * \\
(.00058)\end{array}$ \\
\hline Green_stock $\mathrm{ijt}-1^{2}$ & $\begin{array}{c}2.3 e-07 * * \\
(9.9 e-08)\end{array}$ & & & $\begin{array}{l}1.9 e-07 * \\
(9.9 e-08)\end{array}$ \\
\hline Other_stock $\mathrm{ijt}_{\mathrm{ij}} 2$ & & $\begin{array}{l}.00021 * * \\
(1.0 \mathrm{e}-04)\end{array}$ & & \\
\hline Other_stock ${ }_{\mathrm{ijt}-2}^{2}$ & & $\begin{array}{l}-5.7 \mathrm{e}-09 * * \\
(2.7 \mathrm{e}-09)\end{array}$ & & \\
\hline Green_stock_d $\mathrm{d}_{\mathrm{ijt}-2}$ & & $\begin{array}{l}.10757 * * \\
(.05366)\end{array}$ & & \\
\hline Green_stock $\mathrm{ijt}_{-2}$ & & $\begin{array}{l}-.00131 * * \\
(.00061)\end{array}$ & & \\
\hline Green_stock $\mathrm{ijt}_{\mathrm{ijt}}^{2}$ & & $\begin{array}{l}2.3 e-07 * * \\
(1.1 e-07)\end{array}$ & & \\
\hline Other_stock $\mathrm{ijt}_{\mathrm{j}-5}$ & & & $\begin{array}{l}.00025^{* *} \\
(.00012)\end{array}$ & \\
\hline Other_stock ${ }_{\mathrm{ijt}-5}^{2}$ & & & $\begin{array}{l}-8.4 \mathrm{e}-09 * * \\
(3.9 \mathrm{e}-09)\end{array}$ & \\
\hline Green_stock_d $\mathrm{d}_{\mathrm{ijt}-5}$ & & & $\begin{array}{l}.14644 * * * \\
(.04703)\end{array}$ & \\
\hline Green_stock $\mathrm{ijt}_{-5}$ & & & $\begin{array}{l}-.00162 * * \\
(.00074)\end{array}$ & \\
\hline Green_stock $\mathrm{ijt}-5^{2}$ & & & $\begin{array}{l}3.7 e-07 * * \\
(1.7 e-07)\end{array}$ & \\
\hline Year FE & No & Yes & Yes & Yes \\
\hline $\begin{array}{l}\text { Country-specific year } \\
\text { FE }\end{array}$ & Yes & No & No & No \\
\hline $\begin{array}{l}\text { Country-specific industry } \\
\text { FE }\end{array}$ & Yes & Yes & Yes & Yes \\
\hline $\mathrm{N}$ & 2,936 & 2,876 & 2,696 & 2,889 \\
\hline Groups & 146 & 146 & 146 & 144 \\
\hline $\mathrm{R}^{2}$ within & 0.48 & 0.48 & 0.44 & 0.49 \\
\hline Rho & 0.89 & 0.92 & 0.92 & 0.91 \\
\hline
\end{tabular}

Notes: see Table 2 for the variable definitions; standard errors that are robust to heteroskedasticity and clustered at the industry-country level (clustered sandwich estimator) are in brackets under the coefficients; ***, **, * denote statistical significance at the $1 \%, 5 \%$ and $10 \%$ test level, respectively 
Table 10 Estimates with alternative depreciation rates (fixed-effects regressions for time window 1981-2009)

\begin{tabular}{|c|c|c|}
\hline \multirow[b]{2}{*}{ Depreciation rate } & \multicolumn{2}{|l|}{$\ln \left(q_{i j t}\right)$} \\
\hline & $\begin{array}{l}(1) \\
10 \%\end{array}$ & $\begin{array}{l}(2) \\
30 \%\end{array}$ \\
\hline Constant & $\begin{array}{l}9.5957 * * * \\
(2.0325)\end{array}$ & $\begin{array}{l}9.6752 * * * \\
(2.0068)\end{array}$ \\
\hline $\ln \left(\mathrm{L}_{\mathrm{ijt}}\right)$ & $\begin{array}{l}.89572 * * * \\
(.16948)\end{array}$ & $\begin{array}{l}.88988 * * * \\
(.16782)\end{array}$ \\
\hline $\ln \left(K_{\mathrm{ijt}}\right)$ & $\begin{array}{l}.11045 \\
(.07024)\end{array}$ & $\begin{array}{l}.10955 \\
(.06994)\end{array}$ \\
\hline Other_stock $\mathrm{ijt}_{-1}$ & $\begin{array}{l}.00016^{* *} \\
(7.9 \mathrm{e}-05)\end{array}$ & $\begin{array}{l}.0003^{* *} \\
(.00015)\end{array}$ \\
\hline Other_stock $\mathrm{ijt}-1^{2}$ & $\begin{array}{l}-3.4 \mathrm{e}-09 * * \\
(1.6 \mathrm{e}-09)\end{array}$ & $\begin{array}{l}-1.3 \mathrm{e}-08^{* *} \\
(6.2 \mathrm{e}-09)\end{array}$ \\
\hline Green_stock_d $\mathrm{d}_{\mathrm{ijt}-1}$ & $\begin{array}{l}.08512 \\
(.05791)\end{array}$ & $\begin{array}{l}.08991 \\
(.05796)\end{array}$ \\
\hline Green_stock $\mathrm{ijt}_{-1}$ & $\begin{array}{l}-.00103^{* *} \\
(.00049)\end{array}$ & $\begin{array}{l}-.00181^{* *} \\
(.00088)\end{array}$ \\
\hline Green_stock ${ }_{\mathrm{ijt}-1}^{2}$ & $\begin{array}{l}1.4 e-07 * * \\
(6.9 e-08)\end{array}$ & $\begin{array}{c}4.8 e-07 * \\
(2.4 e-07)\end{array}$ \\
\hline Year FE & Yes & Yes \\
\hline Country-specific industry FE & Yes & Yes \\
\hline $\mathrm{N}$ & 2,936 & 2,936 \\
\hline Groups & 146 & 146 \\
\hline $\mathrm{R}^{2}$ within & 0.48 & 0.48 \\
\hline Rho & 0.91 & 0.91 \\
\hline
\end{tabular}

See Table 2 for the variable definitions; standard errors that are robust to heteroskedasticity and clustered at the industry-country level (clustered sandwich estimator) are in brackets under the coefficients; ***, **, * denote statistical significance at the 1,5 and $10 \%$ test level, respectively

\section{References}

Aghion P, Bloom N, Blundell R, Griffith R, Howitt P (2005) Competition and innovation: an inverted-U relationship. Q J Econ 120(2): 701-728

Aghion P, Veugelers R, Serre C (2009) Cold start for the green innovation machine. Bruegel Policy Contribution, 2009/12, Bruegel, Brussels

Aghion P, Dechezleprêtre A, Hemous D, Martin R, Van Reenen J (2012) Carbon taxes, path dependency and directed technical change: evidence from the auto industry. NBER Working Paper No. 18596

Arrow KA (1962) Economic welfare and the allocation of resources to invention. In: Mirowski P, Sent EM (eds) Science bought and sold. The University of Chicago Press, Chicago, 2002, pp 165-180

Barney J (1991) Firm resources and sustained competitive advantage. J Manag 17:99-120

Barney J, Wright M, Ketchen DJ (2001) The resource-based view of the firm: ten years after 1991. J Manag 27:625-641

Beise M, Rennings K (2005) Lead markets and regulation: a framework for analyzing the international diffusion of environmental innovations. Ecol Econ 52(1):5-17

Bloom N, Van Reenen J (2002) Patents, real options and firm performance. Econ J 112(478):97-116 
Cockburn I, Griliches Z (1988) Industry effects and appropriability measures in the stock market's valuation of R\&D and patents. Am Econ Rev 78(2):419-423

Crepon B, Duguet E, Mairessec J (1998) Research, innovation and productivity: an econometric analysis at the firm level. Econ Innov New Technol 7(2):115-158

Danneels E (2002) The dynamics of product innovation and firm competences. Strateg Manag J 23:1095-1121

Dasgupta P, Stiglitz J (1980) Industrial structure and the nature of innovative activity. Econ J 90(358):266-293

Faber A, Frenken K (2009) Models in evolutionary economics and environmental policy: towards an evolutionary environmental economics. Technol Forecast Soc Change 76(4):462-470

Figueiredo PN (2002) Does technological learning pay off? Inter-firm differences in technological capabilityaccumulation paths and operational performance improvement. Res Policy 31:73-94

Grilliches Z (1990) Patent statistics as economic indicators: a survey. J Econ Lit 28(4):1661-1707

Guellec D, Van Pottelsberghe de la Potterie B (2004) From R\&D to productivity growth: do the institutional settings and the source of funds of R\&D matter? Oxf Bull Econ Stat 66(3):353-378

Hall BH (1992) Research and development at the firm level: does the source of financing matter? NBER Working Paper No. 4096

Hall BH, Helmers C (2011) Innovation and diffusion of clean/green technology: can patent commons help? National Bureau of Economic Research Working Paper No. 16920

Helm D (2012) The carbon crunch. Yale University Press, New Haven

Henderson R, Cockburn I (1996) The determinants of research productivity in drug discovery. RAND J Econ 27(1):32-59

Himmelberg CP, Petersen BC (1994) R\&D and internal finance: a panel study of small firms in high-tech industries. Rev Econ Stat 76(1):38-51

Huber GP (1991) Organizational learning: the contributing processes and the literatures. Organ Sci 2(1):88-115

Johnstone N, Haščič I, Popp D (2010) Renewable energy policies and technological innovation: evidence based on patent counts. Environ Resour Econ 45(1):133-155

Keller W (2002) Geographic localization of international technology diffusion. Am Econ Rev 92(1):120-142

Lanoie P, Laurent-Lucchetti J, Johnstone N, Ambec S (2011) Environmental policy, innovation and performance: new insights on the porter hypothesis. J Econ Manag Strateg 20(3):803-842

Lybbert T, Zolas NJ (2012) Getting patents and economic data to speak to each other: an 'Algorithmic Links with Probabilities' platform for joint analyses of patenting trade and industrial activity. Working Paper, University of California, Davis

Malerba F (1992) Learning by firms and incremental technical change. Econ J 102(413):845-859

March JG (1991) Exploration and exploitation in organizational learning. Organ Sci 2(1):71-87

Marin G (2014) Do eco-innovations harm productivity growth through crowding out? Results of an extended CDM model for Italy. Res Policy 43(2):301-317

Newbert SL (2007) Empirical research on the resource-based view of the firm: an assessment and suggestions for future research. Strateg Manag J 28:121-146

Noci G, Verganti R (1999) Managing 'green' product innovation in small firms. R\&D Manag 29(1):3-15

OECD (2009) Science Technology and Industry Scoreboard, Paris

OECD (2012) Indicators of Environmental Technologies (ENV-Tech Indicators), OECD, Paris. http://www. oecd.org/dataoecd/4/14/47917636.pdf. Accessed Feb 2012

OECD (2011) OECD STAN database, STAN Industry 2008. www.oecd.org/sti/stan. Accessed May 2011

Penrose E (1995) The theory of the growth of the firm, 3rd edn. Oxford University Press, Oxford

Popp D (2005) Lessons from patents: using patents to measure technological change in environmental models. Ecol Econ 54:209-226

Popp D, Newell RG, Jaffe AB (2010) Energy, the environment, and technological Change. In: Hall BH, Rosenberg N (eds) Handbook of the economics of innovation, Elsevier, North-Holand

Porter ME, van der Linde C (1995) Green and competitive: breaking the stalemate. Harv Bus Rev 73(5):120133

Quintana-García C, Benavides-Velasco CA (2008) Innovative competence, exploration and exploitation: the influence of technological diversification. Res Policy 37:492-507

Rexhäuser S, Rammer C (2014) Environmental innovations and firm profitability: unmasking the Porter hypothesis. Environ Resour Econ 57(1):145-167

Schmoch U, Laville F, Patel P, Fritsch R (2003) Linking technology areas to industrial sectors. Final Report to the European Commission, DG Research. Karlsruhe, Paris, Brighton

Teece DJ, Pisano G, Shuen A (1997) Dynamic capabilities and strategic management. Strateg Manag J 18(7):507-533

Wernerfelt B (1984) A resource-based view of the firm. Strateg Manag J 5:171-180

Williamson OE (1975) Markets and hierarchies. Free Press, New York

Wooldridge JM (2009) Introductory econometrics—a modern approach, 5th edn. South-Western, Mason OH 